\title{
Radical Service Innovation: Influencing Factors and Mode Selection
}

\author{
Di Rong ${ }^{1} \&$ Xu Ming ${ }^{1}$ \\ ${ }^{1}$ Glorious Sun School of Business and Management, Donghua University, P.R. China \\ Correspondence: Di Rong, Glorious Sun School of Business and Management, Donghua University 200051, P.R. \\ China. Tel: 86-188-1733-2644. E-mail: lotusdi0730@126.com
}

Received: July 2, 2014 Accepted: July 23, 2014 Online Published: August 22, 2014

doi:10.5539/ass.v10n18p210 URL: http://dx.doi.org/10.5539/ass.v10n18p210

\begin{abstract}
Service industry has played a pivotal role in the world with the rapid development of world economy in recent years. Innovation in service enterprises has become an important competitive concern in many service industries. In order to reasonably analysis the radical service innovation in this area, this paper explores the influencing factors of radical service innovation by using literature analysis method. And an evaluation index system is established in this paper at same time, which is based on the investigation of 45 service oriented firms from Jiangsu Province, Zhejiang Province and Shanghai in China. Following we set up a mathematical model to evaluate the capability of radical service innovation by using the method of Fuzzy-Analytical Hierarchy Process (FAHP). Thoroughly the service enterprises could evaluate their own innovation ability according to the evaluation process. Furthermore, in order to showing the sense of reasonability, creativeness and scientific, the innovation mode selection and an empirical research to evaluate existed service enterprises are discussed in the following part. This paper tries to supply useful proposes and effective decisions to enterprise's radical service innovation strategic.
\end{abstract}

Keywords: radical service innovation, influencing factors, evaluation index system, innovation mode

\section{Introduction}

The rapid development of global service industry has become the world countries reality which cannot be avoided since 1960s. Now the percentage of global service industry in world economy is reaching to $70 \%$, and service trade accounts for over $20 \%$ of the total world trade. As the main body of innovation, service-oriented enterprises act a dominant role in the developing economy. Generally academics believe that the innovation process has been identified as radial and incremental, which are two important approaches of innovation (Rosanna, 2002). Nowadays radical innovation is becoming more and more significant to service-oriented enterprises. Compared with incremental innovation, radical innovation is more complex and has a higher risk. In order to maintain market share and market position, many service firms are more likely to incremental innovation, which carries a lower risk (Tushman \& Anderson, 1986; O'keefe, 1984). Service enterprises which only researching on incremental innovation will be easily obsoleted by the fierce market and competitors with the successful radical innovation brings huge new market and economic benefits. Although studying on radical innovation is difficult, it is still valuable to promote radical innovation research (Linton, 2004; Walsh, 2004). There are increasing numbers of scholars believe that radical innovation can be induced consciously, and the process can be prepared and controlled. From this point, this paper tries to explore the factors which influencing the radical service innovation, and build a rational and effective innovation evaluation system, which can assess enterprise service innovation ability in service enterprises. At last, the mode selection of radical service innovation is discussed which order effective proposals to service enterprises.

\section{Material Studied}

\subsection{Service Innovation}

In order to get a better understanding of service innovation, it is important to identify the definition of 'Innovation' firstly. The term 'Innovative' originated from Latin, and addresses three distinctions: a. update, b. to create something new, c. changing. The theory of 'innovation' was formatted in the 20th century, and was firstly put forward by Schumpeter. He studied on innovation activities in the second industry which based on manufacturing industry and analysis innovation process by using economic methodology. The so-called innovation refers to introducing a new kind of combination production factors into the production system. 
Schumpeter described five innovation, including new project, new production methods, new market, new material sources and new form of industrial organization, and all these can be summarized as three categories: technological innovation, market innovation and organization innovation. The purpose of innovation is to obtain potential profit.

Service innovation theory initially from Schumpeter's innovation theory. The systematic research for service innovation started from 1980s. Service innovation is a unit integrated with new concept, new target and strategic, new innovation methods, and new patterns (Van der Aa \& Elfring, 2002). There is transformation of innovation concept, renovation of innovation mode or more ways to solve the problem, or provide higher added value (Tidd \& Hull, 2003). Similarly, Sundbo believe that service innovation provide more and better ideas and technology to customers. It is important to improve service innovation connotation, service innovation concept to bring higher profit through providing reform and innovation of service concept process.

\subsection{Influencing Factors of Service Innovation}

The study on influencing factors of service innovation has been paid more attention in recent years. Kwaku (1996) discovered that the influencing factors of service innovation are totally different from the manufacturing which based on the comparison study between Australia manufacturing and service industry. The study of service innovation influencing factors focus on the following aspects:

1) Innovation recourses and innovation ability. Henard \& Szymanski (2001) pointed out that necessary time; money and manpower are the basis elements in service innovation. Service innovation needs certain skills and knowledge support, careful planning and arrangement. Jaw C (2010) made a deep analysis based on 600 service enterprises from service characteristics, market orientation and resource allocation these three aspects to indicate that service characteristics, market orientation have a significant impact on service resource allocation, and resource allocation have an important impact on improving service innovation performance.

2) Service innovation process. Hsiao (2008) believed that service industry faced many different influencing factors including organizations, customers, employees for new service understanding and service technology. Martin \& Chris (1999) pointed out that service enterprises exist problems which cross organization union and boundary fusion, service innovation needs to manage the relationship between enterprises manager, employees and other stakeholders.

3) The role of market orientation. Han (1998) emphasized the importance of market orientation in service innovation mode. If the service organization want to improve the innovation performance, they must be pay more attention to the market reflection, and timely adjust organizational resources. Joshi and Sharma (2004) indicate that due to the needs of the consumers and preference changes over time, service innovation need to continue to focus on the market, take the market as the guidance for innovation activities.

\subsection{Radical Innovation}

The study of radical innovation can be traced from Schumpeter's in 1939. Researchers used a wide variety of terms to describe innovations types, including "revolutionary", "disruptive", "discontinuous" or "breakthrough" (Tushman \& Anderson, 1986; Freeman, 1995; Garcia \& Calantone, 2002). These innovation types are defined according to their effects. Most "technological innovation" concept was developed according to Schumpeter's aspect of view. Grulke (2002) made a deeper analysis from uncertainty and unpredictability of radical service innovation in market, organization and resources aspects. Radical service innovations should be identified as "perpetual beta" that needs permanent updating and fine-tuning (Zomerdijk \& Voss, 2011). Tech-based innovation that fundamentally changed the technological trajectory and improved customer benefits is called "radical innovations" (Benner \& Tushman, 2003; Chandy \& Tellis, 1998; Tushman \& Anderson, 1986).

\subsection{Influencing Factors of Radical Innovation}

The researchers of innovation study have begun to summarize the radical innovation influencing factors since 1980s. Now the influencing factors of radical innovation focus on technology aspects, including the size, depth and target. The main influencing factors can be summarized as following:

1) The enterprise and organizational scale. Rajesh Chandy (2006) believed that customer, knowledge, Customer privileges and market forces can provide new opportunities to radical innovation. Cooper \& Kleinscmhidr (1987) made a deep analysis between different influencing factors and different performance standard from financial performance, window opportunity and market share these three aspects.

2) The perspective of environment. Langrish (1989) pointed out that it is important to enterprises innovation success to have a clear understanding of some market. Aihua $\mathrm{Wu}(2008)$ indicated that influencing factors should 
include technology environment and market environment. Hua He (2010) proposed that important factors of radical innovation to incentive enterprises including innovation highland, the university-industry cooperation, business model and a good industrial development environment these four aspects.

3) The innovation driving force. Christensen \& Raynor (2003) believed that entrepreneurial spirit, corporate culture and values are the most important factors in the radical innovation process. Values affect the enterprise understanding of breakthrough innovation and investment. And they also think that entrepreneur's intervention is helpful to ensure the smooth progress of the project when carrying out the radical innovation type. Gilbert \& Bower (2002) pointed out the important influencing factors lies in the cognition of radical innovation. Senior managers will respond to radical innovative technology or product. If it is not important, the service industry will not invest in and give up the market

\subsection{The Relationship of Technological Innovation and Service Innovation}

Early economists had studies more and had different understanding on the relationship between technology and service. Adam Smith affirmed that technology plays an important role in production, and Marx realized the significance of the role of science and technology. Now many researchers made the deep discussion in the relationship between service innovation and technological innovation. Hauknes (1996) made a deep study in the relationship and thought that there is an interaction channel between technology and service; they interact with each other by using this channel. Miles I $(1978,2005,2008)$ argued that there is a simple "replacing" relationship between service and technology; the enterprises provide service to outside costumers through this replacement. This relationship not only exists in internal enterprises, but also stays in outside customers.

In Veryaer's point of view in 1998, there are many types of radical technology innovation in service firms which could be used to implement radical service innovation, promote service innovation, service types and innovation concept. Namely, the development of service enterprises reflects the process of radical service innovation. Although service play a dominant role in almost all developed economies, technological innovation in service enterprises is scarcely compared with product innovation (Ettlie, 2011; Rosethal, 2004). This paper will discuss a new way that how to evaluate the radical service innovation in service firms and provide the beneficial reference for the enterprise.

\section{Methods}

\subsection{Radical Service Influencing Factors}

Service enterprises have their own industry particularity, which resulting many influence factors of service innovation. At present, a lot of factors analysis focus on specific industries, such as logistics, finance, insurance, manufacturing enterprises etc. It is necessary to figure out whether these influencing factors are applicable to other industry. According to the literature above, we can summarize several influencing factors, including researcher innovation ability, R\&D ability, organization and management innovation ability, marketing ability, co-creation innovation ability and innovative output capacity. Furthermore, there are several secondary factors, like radical innovation $R \& D$ investment, organization structure optimization, ability to provide Customization product, radical service innovation business income etc. Whether these influencing factors can affect the radical service innovation ability in service enterprises, it is still need some more analysis.

\subsection{Evaluation of Radical Service Innovation}

3.2.1 Determine the Evaluation Index System of Weights

$$
\begin{gathered}
M_{j}=\frac{1}{n} \sum_{i=1}^{1} X_{i j} \\
S_{i}=\sqrt{\frac{1}{n-1} \sum_{i=1}^{n}\left(X_{i j}-M_{j}\right)^{2}} \\
C V_{j}=\frac{S_{j}}{M_{j}}
\end{gathered}
$$

According to the influencing factors summarized above, we can figure out the evaluation index preliminary. Building the evaluation model of radical service innovation in service-oriented enterprises need to be scientific, systematic and comprehensive. In order to guarantee its systematicness, scientificalness, comparability and practicalness, we make a deep investigation into 45 service oriented firms from Jiangsu Province, Zhejiang Province and Shanghai, and then make the interviews of experts who come from these enterprises by using the 
method of Delphi. By means of questionnaire survey, this paper collects the data of these Shanghai service enterprises, including 14 general service enterprises, 12 knowledge-intensive service enterprises, 9 manufacturing enterprises and 10 financial service enterprises.

According to the five levels evaluation index-"very important", "more important", "important", "less important", "not very important", corresponding to the score 9,7,5,3,1 respectively. $X_{i j}$ represents $i$-th and $j$-th expert indicators in 70 experts, and there are $a$-th experts and $b$-th indicators. The formulas as follows:

$M_{j}$ is arithmetic average of $j$ indexes which represents the expert's concentration; $S_{i}$ is standard deviation of $j$ index, $C V_{j}$ represents variation coefficient of $j$ index, the smaller the $C V_{j}$, the higher Coordination degree of experts' are. And the service innovation ability evaluation indexes are shown in table below:

Table 1. Radical service innovation evaluation index system

\begin{tabular}{|c|c|c|c|}
\hline \multicolumn{4}{|c|}{ Radical service innovation ability evaluation index system (A) } \\
\hline First-class Indexes & Second-class Indexes & $\begin{array}{l}\text { Arithmetic } \\
\text { average }\end{array}$ & $\begin{array}{l}\text { Coefficient } \\
\text { of variation }\end{array}$ \\
\hline \multirow{3}{*}{$\begin{array}{l}\text { Researcher } \\
\text { innovation ability } B_{l}\end{array}$} & Innovation department staff specialization professional $C_{I I}$ & 7.35 & 0.16 \\
\hline & Investment in staff training $C_{12}$ & 7.15 & 0.17 \\
\hline & The quality of personnel $C_{13}$ & 7.51 & 0.17 \\
\hline \multirow{5}{*}{ R\&D ability $B_{2}$} & radical innovation $\mathrm{R} \& \mathrm{D}$ investment $C_{2 l}$ & 8.03 & 0.16 \\
\hline & $\begin{array}{l}\text { Information and communication technologies(ICT) related } \\
\text { to product innovation } C_{22}\end{array}$ & 7.67 & 0.15 \\
\hline & Independent innovation products $C_{23}$ & 7.89 & 0.18 \\
\hline & $\begin{array}{l}\text { Technology innovation research and development success } \\
\text { rate } C_{24}\end{array}$ & 7.88 & 0.17 \\
\hline & Technology patent $C_{25}$ & 7.75 & 0.17 \\
\hline \multirow{5}{*}{$\begin{array}{l}\text { Organization and } \\
\text { management } \\
\text { innovation ability } B_{3}\end{array}$} & Motivate staff innovation system $C_{31}$ & 7.57 & 0.18 \\
\hline & $\begin{array}{l}\text { Motivate radical innovation of enterprise culture } \\
\text { construction } C_{32}\end{array}$ & 6.77 & 0.17 \\
\hline & Organization structure optimization $C_{33}$ & 6.74 & 0.22 \\
\hline & $\begin{array}{l}\text { Employee collaboration innovation platform and system } \\
C_{34}\end{array}$ & 7.40 & 0.18 \\
\hline & Research and production cooperation with the outside $C_{35}$ & 6.87 & 0.22 \\
\hline \multirow{3}{*}{ Marketing ability $B_{4}$} & Market analysis ability $C_{41}$ & 6.44 & 0.17 \\
\hline & The intensity of marketing $C_{42}$ & 7.35 & 0.21 \\
\hline & Channel innovation ability $C_{43}$ & 7.03 & 0.20 \\
\hline \multirow{3}{*}{$\begin{array}{l}\text { Co-creation } \\
\text { innovation ability } B_{5}\end{array}$} & $\begin{array}{l}\text { Analysis capabilities of Understanding the customer's } \\
\text { demand for radical innovation } C_{51}\end{array}$ & 7.98 & 0.19 \\
\hline & $\begin{array}{l}\text { Ability of Improving radical products based on the } \\
\text { customer suggestions } C_{52}\end{array}$ & 8.06 & 0.18 \\
\hline & Ability to provide Customization product $C_{53}$ & 7.99 & 0.15 \\
\hline \multirow{4}{*}{$\begin{array}{l}\text { Innovative } \\
\text { capacity } B_{6}\end{array}$} & Radical service innovation business income $C_{61}$ & 6.87 & 0.19 \\
\hline & $\begin{array}{l}\text { The proportion of radical innovation business income in } \\
\text { revenue } C_{62}\end{array}$ & 6.77 & 0.23 \\
\hline & $\begin{array}{l}\text { The quality and evaluation of radical innovation product } \\
C_{63}\end{array}$ & 7.32 & 0.18 \\
\hline & $\begin{array}{l}\text { The novelty of radical innovation different from the } \\
\text { original product } C_{64}\end{array}$ & 8.03 & 0.16 \\
\hline
\end{tabular}

According to the index system questionnaires, 34 experts gave the marks based on the importance of each evaluation indexes, and then calculate the importance degree of each index. As Table 1 depicts.

\subsubsection{Buildup Judgment Matrix}

The Weight vector of each element is $\omega=\left(\omega_{1}, \omega_{2}, \cdots, \omega_{\mathrm{n}}\right)^{T}$ and then determine the Judgment Matrix $A=\left(\mathrm{a}_{\mathrm{ij}}\right)_{\mathrm{n} \times \mathrm{n}}$. The foundation of judgment matrix is based on the grade of each element.

In every Judgment Matrix, the relative important degree in every two elements are scaled by the Table 2 below. 
Table 2. Judgment matrix 1-9 ratio scale table

\begin{tabular}{lll}
\hline Scale & Definition & Implication \\
\hline 1 & Equally Important & Two elements are equally important. \\
3 & Weakly Important & One element is slightly more important than the other one. \\
5 & Obviously Important & One element is obviously more important than the other one. \\
7 & Strongly Important & One element is strongly more important than the other one. \\
9 & Extremely Important & One element is extremely more important than the other one. \\
Scaling & Anti comparison & I for j scale is $\mathrm{a}_{\mathrm{ij}}$, on the contrary is $1 / \mathrm{a}_{\mathrm{ij} .}$ \\
\hline
\end{tabular}

\subsubsection{To Solve the Maximum Characteristic Root and the Corresponding Eigenvectors}

The calculus process is according to the judgment matrix $A=\left(\mathrm{a}_{\mathrm{ij}}\right)_{\mathrm{n} \times \mathrm{n}}$, and based on the formula below:

$$
\omega_{1}=\frac{1}{n} \sum_{j=1}^{n} \frac{a_{i j}}{\sum_{k=1}^{n} a_{k j}}(i=1,2, \ldots, n)
$$

And then we can figure out the Weight Vector $\omega=\left(\omega_{1}, \omega_{2}, \cdots, \omega_{\mathrm{n}}\right)^{T}$. Since AHP is the subjective judgment, so we make the check consistency in order to ensure the reliability. If the Consistency Ratio in every n-order matrix is

$C R=\frac{C I}{R I}$, and $C I=\frac{\lambda_{\max }-n}{n-1}$.

According to $A w=\lambda_{\max }$,

and then work out the eigenvalue of maximum of judgment matrix $\lambda_{\max }=\frac{1}{n} \sum_{i=1}^{n} \frac{\sum_{j=1}^{n} a_{i j} \omega_{j}}{\omega_{i}}$

$\mathrm{RI}$ is the mean random consistency index.

\subsubsection{Evaluation Index System Model}

Comprehensive decision-making factors set $U=\left\{U_{1}, U_{2}, \cdots, U_{m}\right\}$ is a cantor set which consist of various factors that influencing the evaluation object. The first-class indexes (the main factors) is $A=\left\{B_{1}, B_{2}, \cdots, B\right.$ i $\}$, the second-class indexes is $B_{i}=\left\{C_{i 1}, C_{i 2}, \cdots, C_{i j}\right\} . B_{i}$ represents $i$-th of first-class indexes. $(i=1,2,3,4,5,6)$.

There is a fuzzy relationship between factors set and evaluation sets. Set $V$ comes from the evaluation results from experts, and stands for the radical service innovation ability, $V=$ \{excellent, good, medium, poor $\}$, that is $V_{i}=\left\{V_{i 1}, V_{i 2}, V_{i 3}, V_{i 4}\right\}$. According to Weight matrices $A_{i}$ and the evaluation matrix $V_{i j}$ which based on AHP, we can calculate the $B_{i}$ evaluation vector in second class evaluation index.

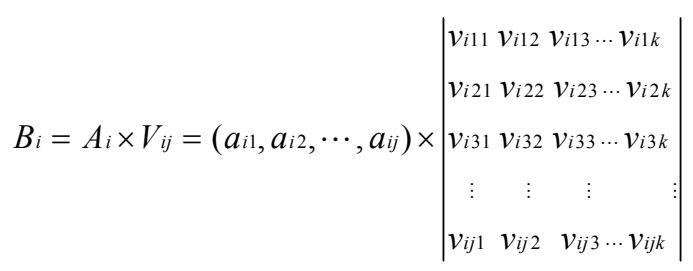

In function (4), $i$ stands for the number of comments, $j$ is for the number of index number.

Integrating the fuzzy evaluation results $B_{i}=\left(b_{i 1}, b_{i 2}, \ldots, b_{i k}\right)$ in the second-level, and makes up the evaluation matrixes $R_{i}$ in the first-level, and then figure out the evaluation results: $B=A R_{i}=\left(a_{1}, a_{2}, \ldots, a_{i}\right)\left(b_{1}, b_{2}, \ldots, b_{k}\right)^{T}$.

\subsection{Radical Service Innovation Mode}

Based on the following calculus process above, we can figure out the radical service innovation mode in this part. Radical service innovation mode is a process to organizing and planning innovation activities in enterprises. It is an institutional arrangement to get the effective innovation by mastering the resources and capabilities. It can be related to the various resources elements during the innovation process. On account of different factors in the combination ways and configuration modes, it can be formed in the different patterns of innovation. Generally, 
the general radical service innovation mode can be divided into three types: independent innovation, imitation innovation mode and cooperative innovation mode showed in Figure 1.

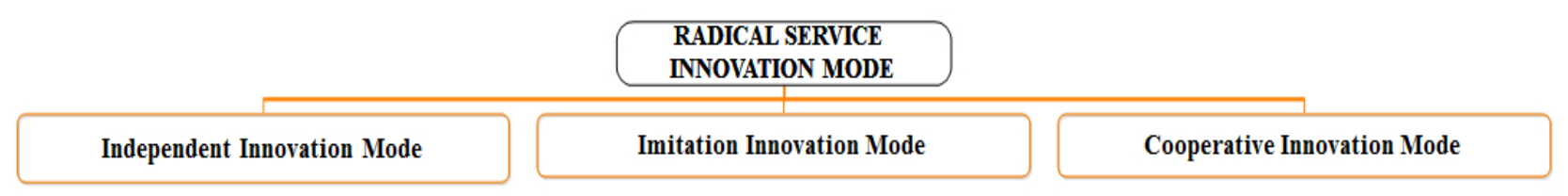

Figure 1. Radical service innovation mode

1) Independent innovation mode. It requires the enterprises to have a higher economic strength, technical research, development capabilities and so on. This mode requires service enterprises which mainly break the innovation difficulties through their own efforts, and form the valuable research results by themselves. This mode requires these enterprises has strong innovation research ability and rich resources without any other cooperator's help. In the whole process of radical service innovation, it is rely on their own ability to complete all the innovation activities. Namely, the market risk is also higher than others, maybe facing failure and dies out.

2) Imitation innovation mode. It is an event which the enterprises imitate other innovators' methods and thoughts. That is work for me in the reasonable range. This innovation mode has a higher requirement of the ability of quickly learning. Imitation innovation mode has a lower risk and investment cost. But this kind of mode is limited easily by technical barriers. Imitation innovation mode is suitable for the firms which have a weak capital and technology relatively.

3) Cooperative innovation mode. The characteristics of this mode are focusing on shortening the time of innovation, undertaking the development risk and cost. It is a joint innovation behavior which among the enterprises, research institutes, colleges and universities. The enterprises have a common target market or try to occupy the market, and then share the profits of the cooperative development. All the parties have certain advantages and the relative parties can realize the complementary resources.

\subsection{The Process of Radical Service Innovation Mode Selection}

These three modes mentioned above are the main innovation types in service enterprises. But the firms cannot easily choose a mode by themselves without any evaluation. In order to selecting the radical service innovation correctly, the enterprises need to understand the innovation ability clearly. Therefore, we make the radical service innovation evaluation below to make a contribution to the enterprises radical innovation.

As shown in the figure below (Figure 2), we build the selection process of radical service evaluation in enterprises. The innovation mode which suitable for the service enterprises is based on the real innovation abilities.

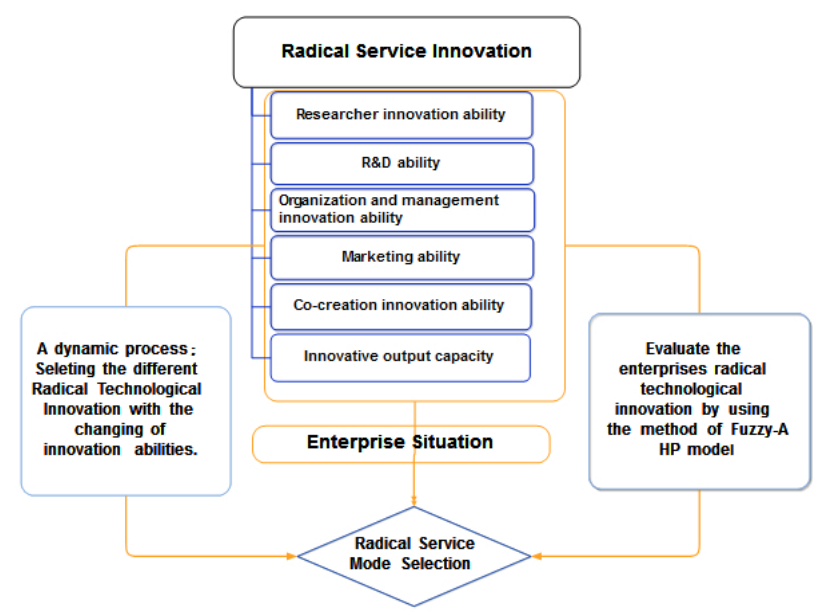

Figure 2. The process of radical service innovation mode 
Based on clearly understanding the radical service innovation ability in service enterprises, the enterprises begin to choose the suitable innovation mode. We can get a rate of radical service innovation by using fuzzy comprehensive evaluation method. Generally, the rating of enterprises is excellent can take Independent innovation Mode (Figure 3). Because they have the strong innovation ability in many aspects, as R\&D innovation ability, Co-creation innovation ability and so on. These kinds of enterprises have rich resource and develop ability. They can make radical service innovation by themselves. Namely, the rating is good and medium. If the strength of enterprises can attract other corporations, these enterprises can choose Cooperative innovation mode. On the contrary, the enterprises can choose Imitation innovation mode when they have a stronger learning ability and have certain economic strength. If the rating of evaluation is poor, the enterprises are not suitable for radical service innovation.

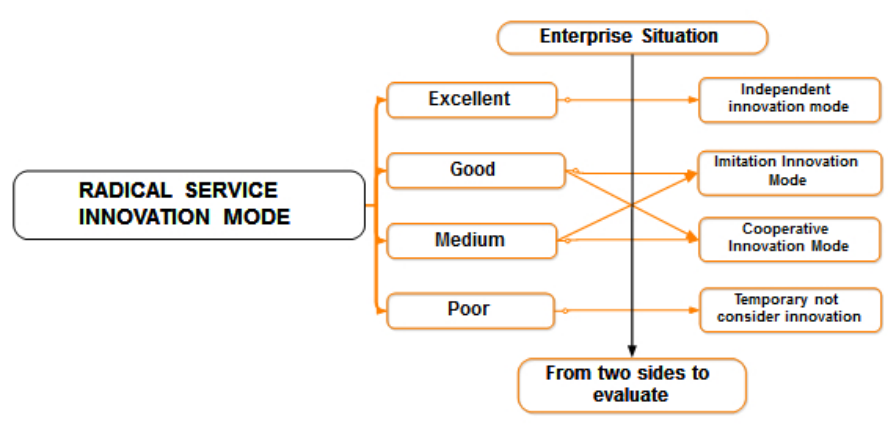

Figure 3. Selection of radical service innovation mode

\section{Results}

There are two service enterprises in Shanghai who have the desire to radical service innovation. Applying the FAHP evaluation model to these service enterprises and they all evaluate their innovation abilities on the following process respectively.

Firstly, determine the Evaluation factors $\operatorname{set} U=\left\{u_{1}, u_{2}, u_{3}, u_{4}, u_{5}, u_{6}\right\} . \mathrm{u}_{1}=$ Researcher innovation ability, $\mathrm{u}_{2}=\mathrm{R} \& \mathrm{D}$ ability, $\mathrm{u}_{3}=$ Organization and management innovation ability, $\mathrm{u}_{4}=$ Marketing ability, $\mathrm{u}_{5}=$ Co-creation innovation ability, Innovative output capacity, $\mathrm{u}_{6}=$ Innovative output capacity.

Secondly, determine the evaluation grade V. V $=\left\{\right.$ Excellent $\mathrm{v}_{1}$, Good $\mathrm{v}_{2}$, Medium $\mathrm{v}_{3}$, Poor $\left.\mathrm{v}_{4}\right\}$. Evaluate the evaluation factors and figure out the Evaluation vectors of each evaluation elements, and form a fuzzy relationship matrix $V$

$\left(U_{i}\right)$

$$
R\left(u_{a}\right)=\left[\begin{array}{cccc}
0.35 & 0.35 & 0.15 & 0.15 \\
0.27 & 0.33 & 0.19 & 0.22 \\
0.26 & 0.24 & 0.21 & 0.22 \\
0.19 & 0.21 & 0.42 & 0.20 \\
0.41 & 0.25 & 0.14 & 0.16 \\
0.29 & 0.27 & 0.12 & 0.23
\end{array}\right] \quad R\left(u_{b)}=\left[\begin{array}{cccc}
0.19 & 0.28 & 0.39 & 0.29 \\
0.22 & 0.14 & 0.35 & 0.25 \\
0.19 & 0.32 & 0.25 & 0.24 \\
0.07 & 0.34 & 0.40 & 0.19 \\
0.22 & 0.26 & 0.23 & 0.37 \\
0.44 & 0.22 & 0.18 & 0.14
\end{array}\right]\right.
$$

Based on the results above, determine the Fuzzy weighted vector A, and then confirm the fuzzy weight distribution $A=(0.16,0.27,0.13,0.21,0.15,0.11)$. According to the formula (1), build the mathematical model of fuzzy comprehensive evaluation.

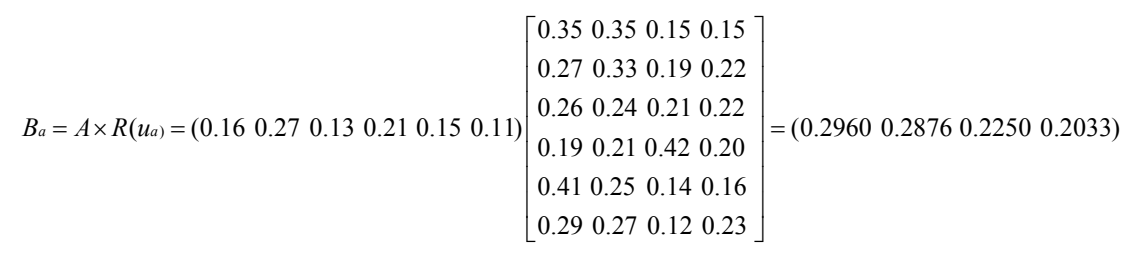




$$
B_{b}=A \times R\left(u_{b}\right)=\left(\begin{array}{llllll}
0.16 & 0.27 & 0.13 & 0.21 & 0.15 & 0.11
\end{array}\right)\left[\begin{array}{llll}
0.19 & 0.28 & 0.39 & 0.29 \\
0.22 & 0.14 & 0.35 & 0.25 \\
0.19 & 0.32 & 0.25 & 0.24 \\
0.07 & 0.34 & 0.40 & 0.19 \\
0.22 & 0.26 & 0.23 & 0.37 \\
0.44 & 0.22 & 0.18 & 0.14
\end{array}\right]=\left(\begin{array}{llll}
0.2106 & 0.2588 & 0.3277 & 0.2559
\end{array}\right)
$$

Thirdly, normalized the processing the results above, and figure out the fuzzy comprehensive evaluation based on the principle of subordination. $\mathrm{Ba}=(0.29600 .28760 .22500 .2033)$, taking the maximum result 0.2960 , the evaluation level is Medium. $\mathrm{Bb}=\left(\begin{array}{l}0.2106 \\ 0.2588\end{array} 0.3277\right.$ 0.2559), taking the maximum result 0.3277 , the evaluation level is Good.

At last, we can give the suggestion to radical service innovation in these service enterprises. Certainly, to take what kind of innovation mode also depends on the enterprise's specific situation. So the evaluation of A and B is good and medium respectively, the imitation innovation and cooperation innovation mode will be more suitable for both of them.

\section{Conclusion}

With rapid development of service enterprises, it is quite important to improve enterprise radical service innovation ability, and scientific methods should be applied to measure enterprise radical service innovation ability. This study provides several managerial implications for firms facilitate radical service innovation.

\subsection{Managerial Implications}

From the literature review and empirical research, we can find that service firms can foster radical service innovation by following the R\&D ability, co-creation innovation ability and researcher innovation ability. Co-creation plays an important role in radical service innovation. Nowadays more and more technological innovation is based on customer requirements. It will be more prone to do research on radical service innovation by focusing on demands of customers.

Radical service innovation has a higher requirement of several innovation abilities, and has a higher risk. It requires not only the sensitivity of obtaining the market demand, but also the effectiveness of innovation management and the decisiveness of making the decision. Furthermore, it is still needed to corporate with other sectors; strengthen communication and cooperation of each department.

\subsection{Limitation and Further Research}

This study is subject to several limitations as an initial effort to address a complicated phenomenon. Service Innovation ability evaluation index system more rely on the static evaluation index, it is not easy dynamically to simulate the effect of changing time, competitive environment on the technological innovation in service-oriented enterprises. Further study can be focusing on the following aspects:

1) Classification for different levels of service innovation. The evaluation index system can based on the Static and dynamic indexes comprehensively. What are the differences among radical service innovation, incremental service innovation and fundamental service innovation? Moreover, radical service innovation ability is relative to the incremental innovation ability, we can do a deeper analysis of combining these two abilities, and make the comparison of these two evaluation systems.

2) At present, the interaction of product services and manufacturing has become a significant trend in the development of world economy, service innovation plays an increasingly important role in promoting economic growth, promote industrial upgrading, stimulate innovation and providing jobs. So what are the differences among radical service innovation, radical product innovation, radical technological innovation and radical business model? Furthermore the differences among innovation content, innovative features and innovation process should be discussed further. And how to successfully implement radical service innovation. All of these need further exploration and research.

3) Pay more attention to ICT and employees. Currently ICT occupies the central position in service innovation, it is quite important to explore the relationship between ICT and radical service innovation. At the same time, enterprises employees play a pivotal role in service innovation and promoting enterprise innovation ability. ICT and employees need to be further discussed in the further study.

\section{References}

Benner, M. J., \& Tushman, M. L. (2003). Exploitation, exploration, and process management: The productivity 
dilemma revisited. Academy of management review.

Chandy, R. K., \& Tellis, G. J. (1998). Organizing for radical product innovation: The overlooked role of willingness to cannibalize. Journal of Marketing Research (JMR). http://dx.doi.org/10.2307/3152166

Ettlie, J. E., \& Rosenthal, S. R. (2011). Service versus Manufacturing Innovation. Journal of Product Innovation Management. http://dx.doi.org/10.1111/j.1540-5885.2011.00797.x

Ettlie, J. E., Bridges, W. P., \& O'keefe, R. D. (1984). Organization strategy and structural differences for radical versus incremental innovation. Management science. http://dx.doi.org/10.1287/mnsc.30.6.682

Freeman, C. (1995). The 'National System of Innovation 'in historical perspective. Cambridge Journal of economics.

Garcia, R., \& Calantone, R. (2002). A critical look at technological innovation typology and innovativeness terminology: A literature review. Journal of product innovation management. http://dx.doi.org/10.1016/S 0737-6782(01)00132-1

Grulke, W. (2002). Lessons in radical innovation: Out of the box-straight to the bottom line. Pearson Education.

Hauknes, J. (1996). Innovation in the service economy. STEP report. Oslo, Norway.

Linton, J. D., \& Walsh, S. T. (2004). Integrating innovation and learning curve theory: An enabler for moving nanotechnologies and other emerging process technologies into production. $R \& D$ Management. http://dx.doi.org/10.1111/j.1467-9310.2004.00359.x

Linton, J. D., \& Walsh, S. T. (2004). Road mapping: From sustaining to disruptive technologies. Technological Forecasting and Social Change. http://dx.doi.org/10.1016/j.techfore.2003.10.004

Marx, K. (2004). Capital: A critique of political economy. Digireads. Com Publishing. http://dx.doi.org/10.1522/ cla.mak.cap2

Miles et al. (1978). Organizational strategy, structure, and process. Academy of management review.

Miles, I. (2005). Innovation in services. The Oxford handbook of innovation.

Miles, I. (2008). Patterns of innovation in service industries. IBM Systems Journal. http://dx.doi.org/10.1147/sj. 471.0115

Richardson, L. E., \& Patricia, K. F. (1995). Gender Differences in Constituency Service among State Legislators. Political Research Quarterly. http://dx.doi.org/10.1177/106591299504800110

Schumpeter, J. A. (1939). Business cycles. New York: McGraw-Hill.

Smith, A., \& Garnier, M. (1845). An Inquiry into the Nature and Causes of the Wealth of Nations. Nelson.

Tushman, M. L. (1986). Anderson P. Technological discontinuities and organizational environments. Administrative science quarterly. http://dx.doi.org/10.2307/2392832

Veryzer, R. W. (1998). Discontinuous innovation and the new product development process. Journal of product innovation management. http://dx.doi.org/10.1016/S0737-6782(97)00105-7

Zomerdijk, L. G., \& Voss, C. A. (2011). NSD processes and practices in experiential services. Journal of Product Innovation Management. http://dx.doi.org/10.1111/j.1540-5885.2010.00781.x

\section{Copyrights}

Copyright for this article is retained by the author(s), with first publication rights granted to the journal.

This is an open-access article distributed under the terms and conditions of the Creative Commons Attribution license (http://creativecommons.org/licenses/by/3.0/). 